\title{
Emotion Judgement Task
}

Dear researchers:

Thank you for your inquiry regarding the Emotion-Situation Knowledge (EK) Judgement Task. The citation for the task is:

Wang, Q. (2021, March 30). Emotion Judgement Task. https://doi.org/10.31234/osf.io/pe5jd

Published works that used this task include the following:

Wang, Q. (2003). Emotion situation knowledge in American and Chinese preschool children and adults. Cognition \& Emotion, 17, 5, 725-746. doi:10.1080/02699930302285

Wang, Q., Hutt, R., Kulkofsky, S., McDermott, M., \& Wei, R. (2006). Emotion situation knowledge and autobiographical memory in Chinese, immigrant Chinese, and European American 3-year-olds. Journal of Cognition and Development, 7, 1, 95-118.

Doan, S. N., \& Wang, Q. (2018). Children's emotion knowledge and internalizing problems: The moderating role of culture. Transcultural Psychiatry, 55(5), 689-709.

Zhang, H. (2018). Relations of Parent-Child Interaction to Chinese Young Children's Emotion Understanding. Journal of Pacific Rim Psychology.

The task has been used with children as well as adults of different cultures. Both English and Chinese versions of the task are provided here. A shortened Chinese version with story pictures is provided in supplemental. This task was first developed and used in Wang (2003). Please refer to the article for a detailed description.

I would very much appreciate your feedback and would like to hear about your research findings with this task.

Qi Wang

Cornell University

Culture \& Cognition Lab

Email: qiwang@cornell.edu 


\section{Instruction}

Present children with 12 short stories about emotion-eliciting situations with a story protagonist depicted as of their age, gender, and ethnicity. Ask children to select one out of four emotion faces (happy, sad, angry, scared) that best shows how the protagonist feels in each story situation.

a. Depending on the gender and ethnicity of the participant child, the protagonist is referred to as Jake (American boy), Jane (American girl), Beibei (Chinese boy), or Lili (Chinese girl), and is described as of the same age as the child at the beginning of the task.

"I'm going to tell you some stories about a little boy, Jake. Jake is 3 years old, just like you!"

b. Introduce emotion faces (happy, sad, angry, and scared) one by one: "This is Jake when he is happy (sad, scared, angry)." Lay out the four faces in front of the child, than ask: "Show me Jake's happy (sad, scared, angry) face." Gently correct children when they make mistakes.

c. Demonstrate the procedure: Tell the pretest story: "This is Jake's birthday. He gets many gifts. He also eats birthday cake and eats his favorite chocolate ice cream." Help the child choose an emotion face depicting the protagonist's feeling state. "How does Jake feel? Show me his face."

d. Test: Present the test stories in a random order. Tell each story with the picture put in front of the child. When telling the story, use a lively, but emotionally neutral tone, pointing to the characters in turn and to the relevant action (if appropriate). For each story, ask: "How does Jake feel? Show me his face." "Good job!" Record children's responses on an answer sheet.

e. A sliding scale can be used to assess the intensity of emotions children perceive in the story character. For a detailed description of the method, see Wang (2003).

Scoring: Children's correct response scores are summed across each emotion. Each child receives four separate scores that correspond to the four emotions, respectively. Correct (normed) responses are listed with the EK stories below. 


\section{$\underline{\text { List of EK stories }}$}

\section{EK Stories (boy):}

Pretest story: Birthday. Today is Jake's birthday. He gets many gifts. He also eats birthday cake and eats his favorite chocolate ice cream.

$\underline{1 .}$ Winning a competition. One day, Jake is running in a race with other kids. He runs very hard and comes in first. He gets a gold trophy. (happy)

2. Adult award for a good deed. One evening, Mommy is cooking dinner. She is very busy. But the garbage-bag is full. So Jake helps Mommy take out the garbage. Mommy says he is a good child. (happy)

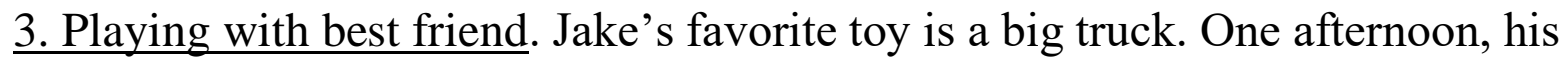
best friend Tommy comes over. The two boys get to play with the truck together. (happy)

4. Losing favorite toy. Jake's parents bought him a Teddy bear. Jake likes the bear a lot. One day, Jake takes his bear out to play and loses it. (sad)

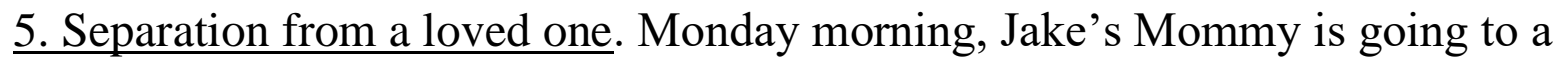
city very far away on a business trip. Jake can't go there with Mommy. He has to stay at home. (sad)

6. Nightmare. One night, Jake has a nightmare. He dreams of a big monster chasing him. The monster has a very big head, a very long nose, and very sharp teeth. (fear)

7. Getting lost in a store. Sunday afternoon, Jake goes to the market with Mommy. There are so many toys in the store! Jake can't keep his eyes off them. Then he gets lost and can't find Mommy. (fear) 


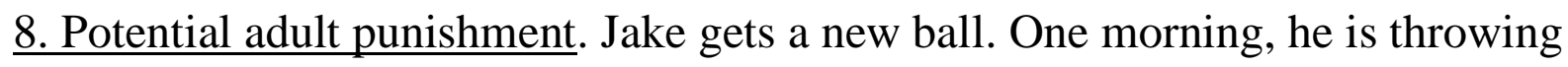
the ball in his room and breaks a big mirror. Daddy hears a crash and rushes in to see what's wrong. (fear)

9. Being forced to do something. Mommy bought Jake a new hat. Jake thinks the hat is really ugly. But Mommy insists that he wear it when he goes out. (anger) 10. Peer aggression. One day, Jake is biking in the yard. The next-door neighbor Max comes over and wants to ride his bike. Jake asks him to wait for a minute. But Max pushes Jake off the bike. (anger)

11. Adult breaking promise. Jake's Daddy has promised to take him to the amusement park this Saturday. But today, Daddy tells Jake that Daddy is going fishing this Saturday and can't take him to the amusement park. (anger or sad) 12. Social rejection. At the playground, Jake sees his three friends building a big sandcastle together. He goes over and wants to join them. But his friends don't play with him. (anger or sad) 


\section{EK Stories (girl):}

Pretest story: Birthday. Today is Jane's birthday. She gets many many gifts. She also eats birthday cake, and eats her favorite chocolate ice-cream.

1. Winning a competition. One day, Jane is running in a race with other kids. She runs very hard and comes in first. She gets a gold trophy.

2. Adult award for a good deed. One evening, Mommy is cooking dinner. She is very busy. But the garbage-bag is full over. So Jane helps Mommy take out the garbage. Mommy says she is a good child.

3. Playing with best friend. Jane's favorite toy is a pretty dolly. One afternoon, her best friend Jessie comes over. The two girls get to play with the dolly together.

4. Losing favorite toy. Jane's parents bought her a Teddy bear. Jane likes the bear a lot. One day, Jane takes her bear out to play and loses it.

5. Separation from a loved one. Monday morning, Jane's Mommy is going to a city very far away on a business trip. Jane can not go there with Mommy. She has to stay at home.

6. Nightmare. One night, Jane has a nightmare. She dreams of a big monster chasing her. The big monster has a very big head, a very long nose, and very sharp teeth.

7. Getting lost in a store. Sunday afternoon, Jane goes to the market with Mommy. There are so many toys in the store! Jane can't keep her eyes off them. Then she gets lost and can't find Mommy.

8. Potential adult punishment. Jane gets a new ball. One morning, she is throwing the ball in her room and breaks a big mirror. Daddy hears a crash and rushes in to see what's wrong. 
9. Being forced to do something. Mommy bought Jane a new hat. Jane thinks the hat is really ugly. But Mommy insists that she wear it when she goes out.

10. Peer aggression. One day, Jane is biking in the yard. The next-door neighbor Sarah comes over and wants to ride her bike. Jane asks her to wait for a minute. But Sarah pushes Jane off the bike.

11. Adult breaking promise. Jane's Daddy has promised to take her to the amusement park this Saturday. But today, Daddy tells Jane that Daddy is going fishing this Saturday and can't take her to the amusement park.

12. Social rejection. At the playground, Jane sees her three friends building a big sandcastle together. She goes over and wants to join them. But her friends don't play with her. 


\section{情绪故事 (男孩)}

例子 这天贝贝过生日。他收到了很多很多的礼物。他还吃了生日蛋糕, 还 有他最爱吃的巧克力冰淇淋。

故事 1 一天, 贝贝和小朋友们一起参加赛跑。他使劲跑呀跑，跑了第一名， 得了一个金奖杯。

故事 2 这天晚上，妈妈正在做饭，特别忙，可是垃圾桶都满出来了。贝贝 就帮妈妈到掉了垃圾。妈妈夸他是个好孩子。

故事 3 贝贝最心爱的玩具是一辆大卡车。这天下午，他最好的朋友乐乐来 他家。两个小男孩就一起玩这辆大卡车。

故事 4 贝贝的爸爸妈妈给他买了一个线毛小熊。贝贝特别喜欢这个小熊。一天， 贝贝带着他的小熊出去玩，把小熊给丢了。

故事 5 星期一的早晨, 贝贝的妈妈要去一个很远的地方出差。贝贝不能 跟妈妈一起去, 只能呆在家里。

故事 6 一天夜里, 贝贝做了一个恶梦。他梦见一个大妖怪在后面追他。这 个大妖怪头特别大，鼻子好长，牙齿很尖。

故事 7 星期天下午, 贝贝和妈妈一起上街。商店里玩具可多了, 贝贝看得 着了迷。一会儿他就走丢了, 找不到妈妈了。

故事 8 贝贝得了一个新皮球。这天早晨，他在房间里扔皮球玩，把一面大 
镜子打碎了, “哗啦......”。爸爸听见了声音, 赶紧跑进来看出了什么事。

故事 9 妈妈给贝贝买了一顶新帽子。贝贝觉得这帽子特难看, 但是妈妈非 要他出门时戴上。

故事 10 一天, 贝贝正在院子里骑自己的小自行车玩。对门的强强走过来 要骑他的 车。贝贝让他稍等一会儿, 但强强一下就把贝贝推下了车。

故事 11 贝贝的爸爸答应这个星期天带他去游乐场玩。但是今天, 爸爸告诉 贝贝说星期天爸爸要去钓鱼, 就不能带他去游乐场了。

故事 12 在操场上, 贝贝看见他的三个朋友正在用砂子堆一个大城堡。贝贝 走过去要跟他们一起玩, 但他的朋友不跟他玩。 


\section{情绪故事 (女孩)}

例子这天丽丽过生日。她收到了很多很多的礼物。她还吃了生日蛋糕, 还 有她最爱吃的巧克力冰淇淋。

故事 1 一天，丽丽和小朋友们一起参加赛跑。她使劲跑呀跑，跑了第一名， 得了一个金奖杯。

故事 2 这天晚上，妈妈正在做饭，特别忙，可是垃圾桶都满出来了。丽丽 就帮妈妈到掉了垃圾。妈妈夸她是个好孩子。

故事 3 丽丽最心爱的玩具是一个漂亮的洋娃娃。这天下午, 她最好的朋友 婷婷来她家。两个小女孩就一起玩这个洋娃娃。

故事 4 丽丽的爸爸妈妈给她买了一个线毛小熊。丽丽特别喜欢这个小熊。一天， 丽丽带着她的小熊出去玩, 把小熊给丢了。

故事 5 星期一的早晨，丽丽的妈妈要去一个很远的地方出差。丽丽不能 跟妈妈一起去, 只能呆在家里。

故事 6 一天夜里, 丽丽做了一个恶梦。她梦见一个大妖怪在后面追她。这 个大妖怪头特别大，鼻子好长，牙齿很尖。

故事 7 星期天下午, 丽丽和妈妈一起上街。商店里玩具可多了, 丽丽看得 着了迷。一会儿她就走丢了, 找不到妈妈了。 
故事 8 丽丽得了一个新皮球。这天早晨，她在房间里扔皮球玩，把一面大 镜子打碎了, “哗啦......”。爸爸听见了声音，赶紧跑进来看出了什么事。

故事 9 妈妈给丽丽买了一顶新帽子。丽丽觉得这帽子特难看, 但是妈妈非 要她出门时戴上。

故事 10 一天, 丽丽正在院子里骑自己的小自行车玩。对门的欣欣走过来 要骑她的 车。丽丽让她稍等一会儿, 但欣欣一下就把丽丽推下了车。

故事 11 丽丽的爸爸答应这个星期天带她去游乐场玩。但是今天，爸爸告诉 丽丽说星期天爸爸要去钓鱼, 就不能带她去游乐场了。

故事 12 在操场上，丽丽看见她的三个朋友正在用砂子堆一个大城堡。丽丽 走过去要跟她们一起玩，但她的朋友不跟她玩。 
The following images are copyright protected. You are welcome to use them in your research. Please do NOT include them in your research report for publication. 图片版权所有, 只供研究使用, 请尊重!
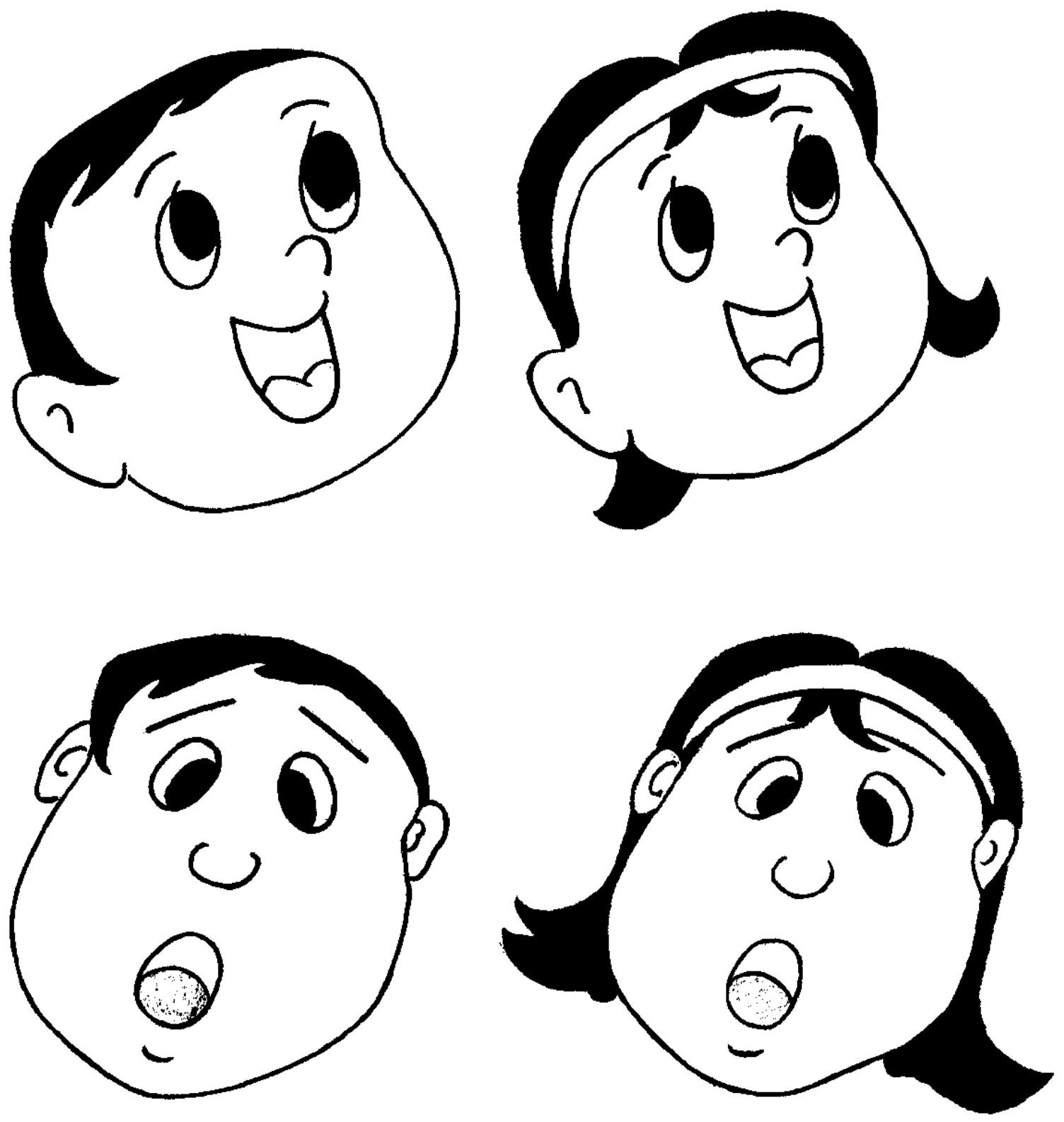

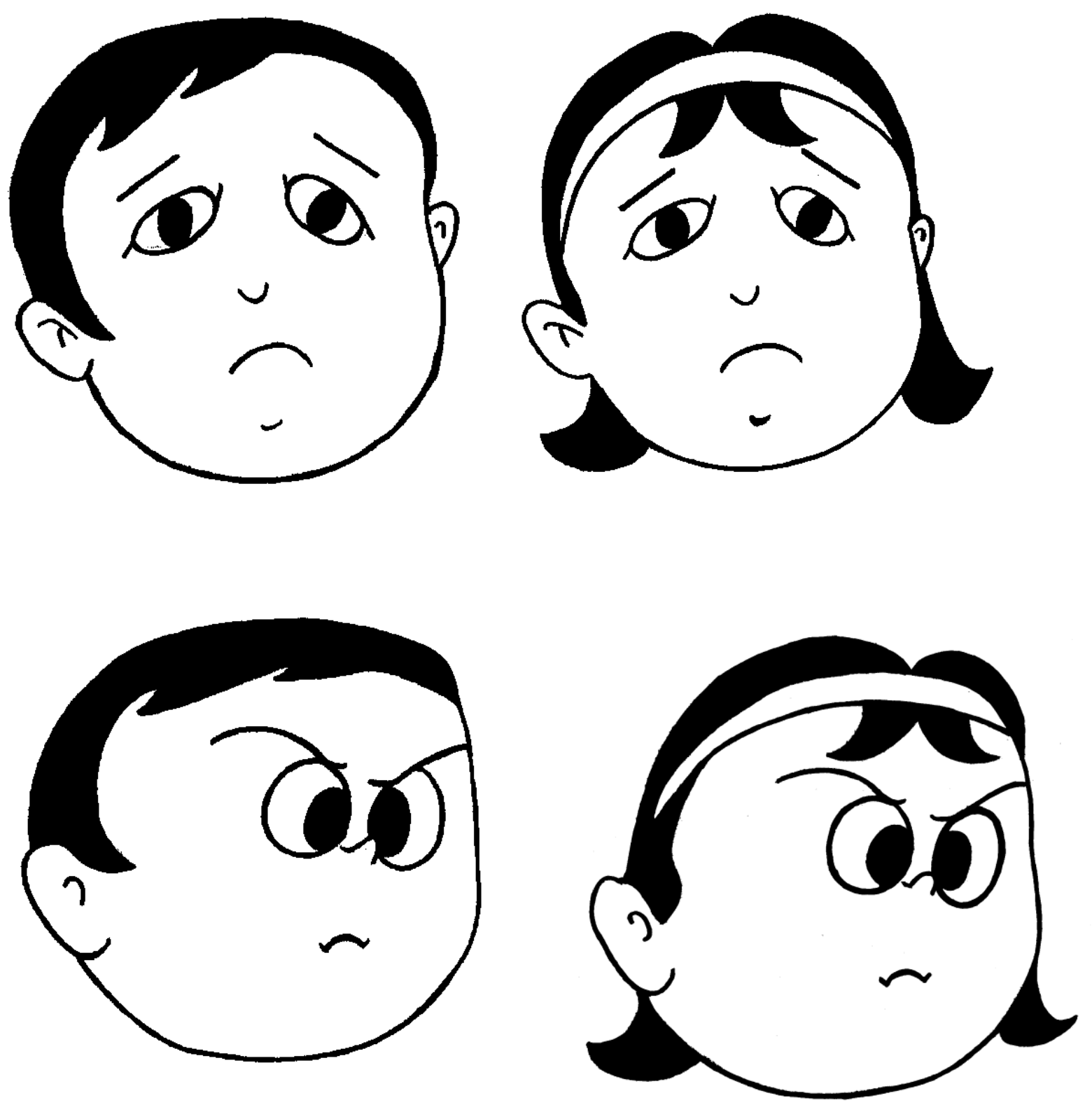

(C) 